\title{
Idiosyncrasies of Money: 21st Century Evolution of Money
}

\author{
Daniel Ogachi ${ }^{1, * \mathbb{D}}$, Paul Mugambi ${ }^{2}$, Lydia Bares ${ }^{3}(\mathbb{D})$ and Zoltan Zeman ${ }^{4}$ (D) \\ 1 Doctoral School of Economics and Regional Sciences, Hungarian University of Agriculture and Life Science, \\ 2100 Gödöllő, Hungary \\ 2 Doctoral School of International Relations and Political Science, Corvinus University of Budapest, \\ 1093 Budapest, Hungary; paulmakunyi@yahoo.com \\ 3 Department of General Economics, University of Cadiz, 11002 Cadiz, Spain; lydia.bares@uca.es \\ 4 GTK Institute of Finance, Accounting and Controlling, Hungarian University of Agriculture and Life Science, \\ 2100 Gödöllő, Hungary; zeman.zoltan@gtk.szie.hu \\ * Correspondence: ogachdniel@gmail.com; Tel.: +254-728269396
}

Citation: Ogachi, Daniel, Paul Mugambi, Lydia Bares, and Zoltan Zeman. 2021. Idiosyncrasies of Money: 21st Century Evolution of Money. Economies 9: 40. https:// doi.org/10.3390/economies9010040

Academic Editor: Sajid Anwar

Received: 13 February 2021

Accepted: 5 March 2021

Published: 16 March 2021

Publisher's Note: MDPI stays neutral with regard to jurisdictional claims in published maps and institutional affiliations.

Copyright: (c) 2021 by the authors. Licensee MDPI, Basel, Switzerland. This article is an open access article distributed under the terms and conditions of the Creative Commons Attribution (CC BY) license (https:// creativecommons.org/licenses/by/ $4.0 /)$.

\begin{abstract}
This paper examines the question of what kind of money will govern the 21st century by examining the developments which characterise this landscape. On the basis of a review of the available literature and evidence, it is clear that certain technological innovations, such as the movement towards electronic money, will undoubtedly change how we operate. However, the conclusion in this paper is less sanguine regarding the prospects of a global currency, regional monetary unions, or states' exit from or central banks' control of money. This paper also sees poor prospects for cryptocurrencies at the moment, given their focus on the decentralisation and politicisation of money, because money requires a backstopping force, making it inherently political. Finally, this paper considers how regulators may seek to ensure that money in its digital form is not taken advantage of and applied in malevolent activities. The study used correlation to establish the level of association among variables. A multiple regression analysis was used to draw an econometric model explaining the relationship between the independent and dependent variables. The following variables were used as independent variables: monetary aggregate (M1), harmonised index of consumer prices (HICP), Euro Interbank Offered Rate (EURIBOR), US dollar/euro, and the USD value of Bitcoin. Multiple regression predicted that when inflation rises, the money supply will decrease. M1 includes cash in circulation, current deposits, and other than demand deposits. The study concludes that price increases encourage people to keep their money in longer-term deposits, including in cryptocurrency. Additionally, an increase in EURIBOR and US dollar/euro reduces the supply of money. Otherwise, an increase in the price of bitcoin in the economy would increase the overall money supply.
\end{abstract}

Keywords: currency; central banks; cryptocurrencies; digital money; money evolution

\section{Introduction}

Money performs various economic functions in society: as a store of value, as a unit of account, and as a medium of exchange (Carstens 2019). Money is really what money does (Hicks 1979). People are usually willing to accept whatever "thing" is described as money purely on the basis of trust that others will also accept this "thing" in exchange for goods and services. Remove this trust, which is a function of future expectations, and the coins, notes and other things that are referred to as money become worthless. In this sense, money can adequately be described as a social convention or a social contrivance. It is little wonder, then, that the thing that has represented money over the centuries worldwide has mutated according to circumstances. For instance, there have been times during which money was represented by cowrie shells, cigarettes, stones, gold, coins, and notes, and now, money is increasingly being represented in electronic formats (Carstens 2019). This all feeds back to the point that money is a social convention and that the thing that symbolises 
it is not as important as the trust and belief that accompanies such representations of money. Indeed, there has been a movement towards the abstraction of money in the form of digital cash and other electronic forms of money in recent years.

Nevertheless, how are people to be assured that other people will, both now and in the future, accept coins, notes or other representations as money and exchange them for valuable goods and services? The state has always been important in providing the much-needed backstop for currency. In virtually all jurisdictions, the state, acting through central banks, can issue new money and regulate all other financial institutions that create intermediate money. However, partly as a result of the 2008 global financial crisis and partly due to technological evolution, a movement has also arisen that seeks to decentralise money by removing the state from the issuance of money, with the aim of better managing financial crises. Consequently, cryptocurrencies have evolved, whose key feature is the decentralisation of money, with a fixed supply of money replacing the current centralised fiat money. There has also been debate with respect to the need for digital currencies issued by the central bank to replace the state's notes and coins.

Globalisation has also led to the increasing convergence of governance institutions, including through the formation of regional blocs and regional economic organisations that have economic integration as one of their central objectives. The European Economic Community, comprising most of the countries in continental Europe, heavily informed the European Union, with many members adopting a single common currency, the euro. As globalisation intensifies, making the world a global village, is there the potential for a global currency to arise? If this were to happen, coupled with the arguments in favour of the decentralisation of money that continue to reverberate, who would have the ultimate control over money? The state, which has traditionally had the royal prerogative of issuing and controlling money, may give way to private actors, or else the state may exert even more control over money. Moreover, given the increasing complexity of this subject and the various forms that money is bound to take, there is the potential for money to be used to further criminal activities.

For centuries, money has been at the heart of human relationships; the loss of confidence in the value of one's beliefs can lead to both financial and political bankruptcy and even armed conflict. Within the last few years, financial technology has captured the world's attention by providing non-traditional payment options. Most academics agree that so-called "cryptocurrencies" lack all of the attributes of money. While they believe the concept to be highly transformational, they also believe that distributed ledger technology could remove the intermediary in payment services. This would undermine the power of central banks and state influence over the money supply. Indeed, decentralised digital currencies were created with the intent of circumventing central banking regulations. At present, less than one-half of all monetary transactions in Sweden are carried out in cash, as opposed to the 13 per cent of current operations noted by the governor of the Swedish central bank. In the age of banknotes and coins, people would be out of work if they were not paid in cash.

Digital platforms are reshaping relationships between customers, workers and employers as the silicon chip reach permeates almost everything we do-from buying groceries online to finding a partner on a dating website. As computing power improves dramatically and more and more people worldwide participate in the digital economy, we should think carefully about devising policies that will allow us to fully exploit the digital revolution's benefits while minimising job dislocation. This digital transformation results from what economists who study scientific progress and technical change call a general-purpose technology, one with the power to continually transform itself, progressively branching out and boosting productivity across all sectors and industries. Such transformations are rare. Only three previous technologies earned this distinction: the steam engine, the electricity generator, and the printing press. These changes bring enormous long-term benefits.

Financial stability is a requirement of modern market economies. Events have demonstrated that financial institutions cannot be considered reliable over the past decade if 
the value of money is not constant. There is a large body of evidence that demonstrates that prosperity is threatened when money is fluctuating. Stopping its loss of value has become the primary, if not the sole, central banks' focus. Money's necessity-and the critical role of governments and central banks in its provision-will be discussed from many different angles. After more than a thousand years of circulation, the number of "monies" began to drop dramatically in the final millennium. It is superficial because many national currencies were not as valuable as "money". Some "units of value" do not need to be defined in terms of a monetary unit.

The term "monetary policy" can describe central banks' actions only for the few currencies that serve as money standards. Policies like these determine the long-term quality of money. In a market economy, the quality of money is linked to the resources used alongside money in money-type functions. In highly volatile markets, people hold onto their money, use it less, make more frequent cash purchases, require more cash managers, and employ financial advisers who charge a great deal. For small investors, the money of lower quality means that more time, effort, and money, and thus resources, are invested in collecting prices and making comparisons. Thus, those resources could have supported "socially beneficial policies" that maintained a sound money supply. The frequently mentioned but little understood "cost of inflation" is the loss of production over time as money deteriorates (Jordan 2005).

\section{Money of the 21st Century and Beyond}

For about three millennia, money has been part of human civilisation and relationships, enabling the exchange of valuable goods and services by acting as a medium of exchange. Before the invention of money, most of the exchange of goods and services used to occur through barter trade. In bartering, one person would bring particular goods to the marketplace and, in turn, obtain another kind of goods that they did not have from another person or trader. In essence, goods and services could only be exchanged for others as there was nothing else that could compensate one for their goods, nor was there any money to acquire that they desired. Most of the goods employed in the barter trade included cattle, sheep, vegetables and grain. The need for currency or money arose owing to difficulties of ascertaining value to attach to particular goods and services.

Coinage, the practice of minting small pieces of metal with distinctive marks, which appeared in the second half of the 7th century BC, had a transformative effect on ancient economies and societies. Controversies persist concerning ancient coinage's original function, particularly states and markets' role in their emergence. Information-theoretic measures to a corpus of 6859 different coins from the Ancient Mediterranean world, dated between c. 625 and c. $31 \mathrm{BCE}$, show that symbols minted on coins have become increasingly informative about a coin's value. This trend was specific to value-relevant information, as distinct from information on issuing states. Coin designs also provided more information about higher denominations than about lower denominations. Before the numerical or written value marks were widely used for coinage, these iconic symbols were carrying financial information (Pavlek et al. 2019).

King Alyattes created the first known and documented currency in Lydia, which now forms part of modern-day Turkey, around 600 BC (Burn-Callander 2019). On the other hand, the first coin ever minted featured a roaring lion on its face. The history of paper money dates back to the twelfth and thirteenth centuries, a chapter by Marco Polo in Cathay's book (Tullock 1957). Around 1661 AD, banknotes were printed in Sweden, with the first credit card in the world appearing in 1946. We now speak of cryptocurrencies such as bitcoins, credit cards, and other electronic money forms in this century.

Swedish households have begun to rely more on electronic means of payment, such as bank cards and Swish, while cash use is declining. In terms of electronic payment methods, debit cards are still widely used, but Swish makes a more considerable impact. The survey results show that $80 \%$ of respondents used a debit card to make their most recent purchase. The corresponding figure for 2016 was $64 \%$. Six out of ten respondents reported that 
they used the mobile payment service Swish in the past month, and the same number of respondents reported using cash. While cash usage is declining, few people encounter problems with shops refusing to accept cash payments. The way payment is made also differs based on the population, where younger people prefer electronic payments to a greater extent. Overall, the use of cash in rural areas is about the same as it was in the last survey, but in rural areas, the usage of cash is slightly more significant than it is for the country as a whole (Sveriges Riksbank 2018a).

As cryptocurrencies' development continues, their popularity and spread of trading rapidly increase. The high volatility of these assets is encouraging in that it allows users to study and anticipate the price of these assets in an ever-changing market environment (Batrancea et al. 2020a, 2020b). Mikhaylov (2020), who discovered EOS cryptocurrency, stated that it was the most effective and promising digital currency. It is simple to use and offers the lowest cost in commissions compared to the other analysed cryptocurrencies, and enables third-party applications in the system. However, it has been established that cryptocurrencies exhibit the highest market volatility level, negatively affecting transactions. Bitcoin has been associated with higher volatilities and forecasting problems using data from the largest crypto exchange-Binance (Xie 2019). Studies have established that the most capitalised cryptocurrencies include Bitcoin, Ethereum, Litecoin and Ripple (Bohte and Rossini 2019).

Since Bitcoin, Ether, and over 2000 cryptocurrencies have collectively reached a market capitalisation of over USD 300 billion, a better understanding of their statistical and financial properties is still in demand. Today, numerous economic theories cannot fully explain their characteristics or describe their statistical and econometric attributes, such as their extreme variability and heteroskedasticity. Findings on the relationship between Bitcoin and Ether prices using a Non-Homogeneous Pólya Gamma Hidden Markov (NHPG) model surpass those obtained from conventional financial data. In this instance, results show that all price series are heteroskedastic, which means frequent shifts between the two states of the underlying Markov process. It is somewhat surprising that the Bitcoin and Ether prices, which appear to be correlated, behave differently. Long-term Bitcoin data studies show a significant covariate change over time. Consequently, cryptocurrencies are unlike any other financial asset, and their understanding necessitates novel tools and approaches (Koki et al. 2019).

This paper considers these issues to survey the future of the money landscape and seek to explore future money. It argues that money institutions are likely to continue to face technological changes and evolve accordingly to conform to the increasing complexities and opportunities. In particular, it argues that electronic cash instead of physical cash will rule the 21st century, but not overwhelmingly. However, this paper argues that the emergence of virtual currencies or cryptocurrencies that seek to decentralise money will barely be successful because of the state's resistance and because such currencies do not fulfil the economic functions of money. It is anticipated that increasing globalisation may result in more regional organisations, and there may be a movement towards a global currency that may not materialise in this century. In the final analysis, this paper concludes that the state will still have significant control over money, whatever its form, and proposes some measures to ensure that money is only employed towards fulfilling legal, economic functions.

\section{Methodology}

The methodology followed consists of a literary review of the pronouncements of different documents, publications and financial reports regarding the future of money and digital and virtual currencies. This study analyses the different payment options and money related events including cryptocurrency, digital transactions, internet-based transactions and e-commerce transactions. A search was carried out in the databases of countries' financial platforms to analyse different data sets. Panel data were used in the study for the period between 2010 and 2020. An econometric model was conducted to 
establish trends in money evolution and use. The study used correlation and multiple regression to establish relationships. The variables used in the study included the monetary aggregate (M1), harmonised index of consumer prices (HICP), Euro Interbank Offered Rate (EURIBOR), US dollar/euro and the US dollar value of Bitcoin.

\section{Results}

\subsection{The Future of Cash}

Due to technological innovation and digitalisation, there has been a noticeable trend in recent years towards more money abstraction. In particular, the understanding of "cash being king" has gradually given way to other electronic forms of cash, particularly in Europe and the West. For instance, Nordic countries such as Sweden lead the pack in moving into a cashless society, with cash dropping by 50 per cent. This results from more people choosing to rely on mobile phone applications and debit cards that allow real-time payments. In Sweden, up to half of the banks do not deal in cash, with seven out of ten consumers expressing optimism that they can do without cash, while half of the merchants are expected to no longer deal in cash by the year 2025 (Arvidsson et al. 2018). Concerning payment in stores and supermarkets, only 13 per cent of transactions are conducted in cash (Sveriges Riksbank 2018b). What is more, mobile money, whereby money is transferred through a cell phone, has had tremendous success in countries such as Kenya, where up to EUR 25 billion is transacted annually (Munda 2018).

According to Figure 1, the world is also experiencing a phenomenal growth of contactless payment systems, even as mobile technology becomes more complex and ubiquitous. This has meant that the usage of cash has experienced a significant downturn. For instance, in the United Kingdom (UK), only 34 per cent of all payments were in cash in 2017 (Shaw 2018). Part of this change has been fuelled by the increasingly expensive nature of the infrastructure that underlies and supports cash usage in payment transactions. To illustrate, the setting up of various physical bank branches in various parts and the associated bank charges have eaten into financial institutions' profit margins, thereby making them less competitive.

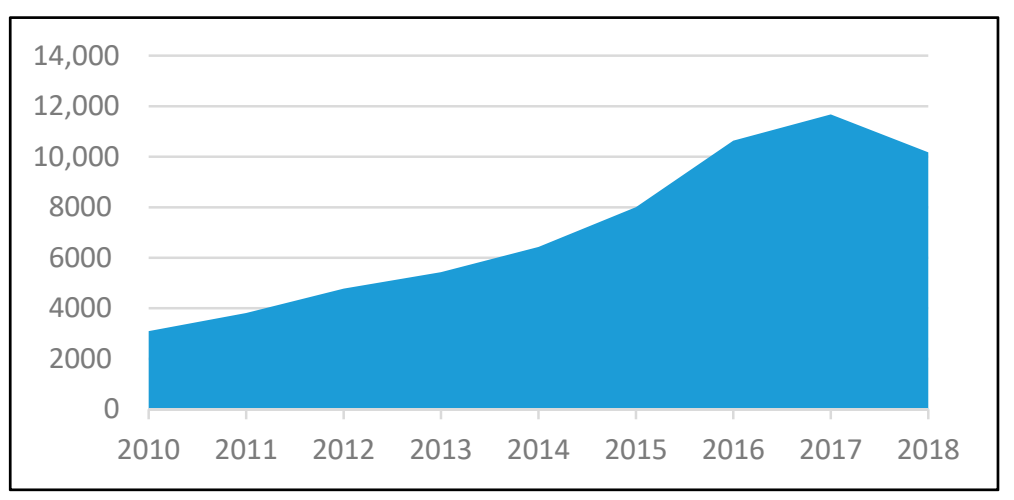

Figure 1. Electronic money-total reported by electronic money institutions in the euro area (20102018). Source: authors' elaboration based on data of the European Central Bank.

Developments have also arisen concerning currencies with the development of crypto assets. These cryptocurrencies were mainly a backlash due to the global financial crisis of 2008/2009, which instilled a measure of scepticism among actors. They thus sought a mechanism to delink money from the state and, in turn, to decentralise it. As noted by He, among others, the creation of currencies such as Bitcoin was an endeavour to challenge the state-sponsored currency paradigm and the role of the traditional dominant financial institutions and regulators, including the Central Banks (He et al. 2017). To some extent, cryptocurrencies move towards the "denationalisation of money", an idea propagated earlier by economist Friedrick Hayek (Hayek 1976). 
Some benefits accrue to a cashless society compared to the one we are primarily familiar with that mainly uses physical cash in the form of notes or coins (Figure 2). Firstly, the anonymity and untraceable nature of physical cash make it more susceptible to being used in furtherance or commission of illegal and illicit activities, such as tax evasion, bribery, corruption, terrorist financing and counterfeiting (Young 2013). A study by Amiram et al. (2020) established contradictory findings to a study by Young and reported that blockchain-based cryptocurrencies were used to finance terrorist attacks.

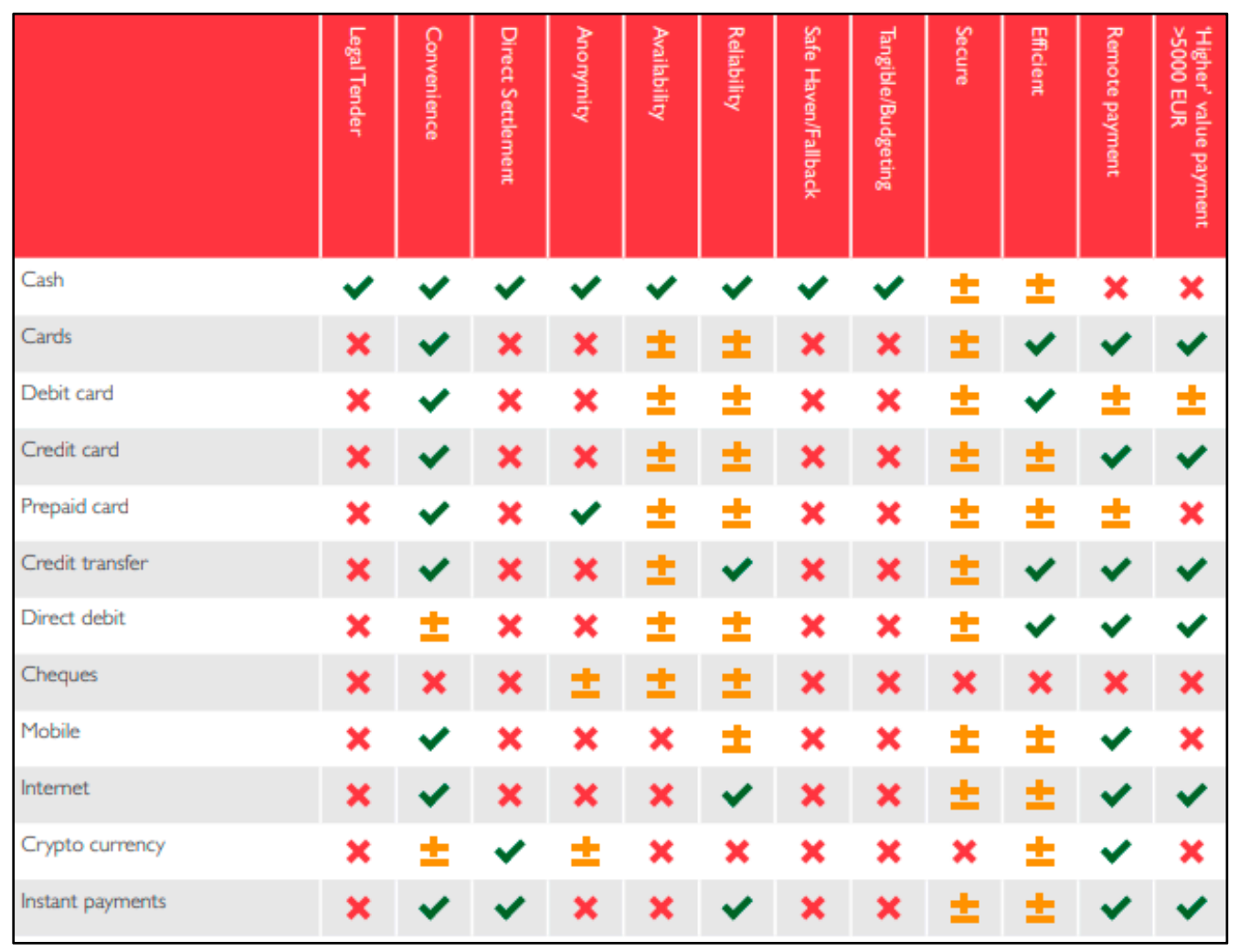

Figure 2. Scoring of payment instruments on crucial attributes of payments. Source: Group 4 Securicor (G4S) and Payments Advisory Group analysis, 2018.

On the other hand, contactless payments or electronic cash leave an audit trail for the mere reason that the payer and the receiver are easily identifiable by checking the electronic payment system. Additionally, one can quickly tell the source of one's money used in a transaction. Secondly, a cashless society may be more secure than one manned by physical cash. This is because one is less likely to be confronted by robbers or suffer physical violence if they have no physical cash compared to if they do. Various technologies applied in electronic payments, including retina scanning and face and voice recognition that verify and validate transactions, are potentially more secure. This may be added to end encryption that sometimes accompanies payment systems that make it less likely to decode, thus boosting such electronic platforms' safety and security. Thirdly, an economy that relies on digital cash is better able to conduct its monetary policy through the central bank as people are not usually able to hoard cash when central banks lower interest rates in a bid to stimulate a depressed economy, thus going around the zero lower bound theory of interest rates (Singh 2014). Finally, electronic money may have the positive effect of reducing bank runs given that depositors may not be able to withdraw the physical cash from the banks and keep it at home. At best, depositors would only move the electronic money from one financial institution to another, but not remove such money from the financial system. The most often-mentioned reason for the change in perception was the fact that electronic payments have been made more convenient during the pandemic, e.g., 
by increasing the threshold for the contactless cardholder having to enter his/her personal identification number (PIN) for payment authorisation into the card terminal (Figure 3).

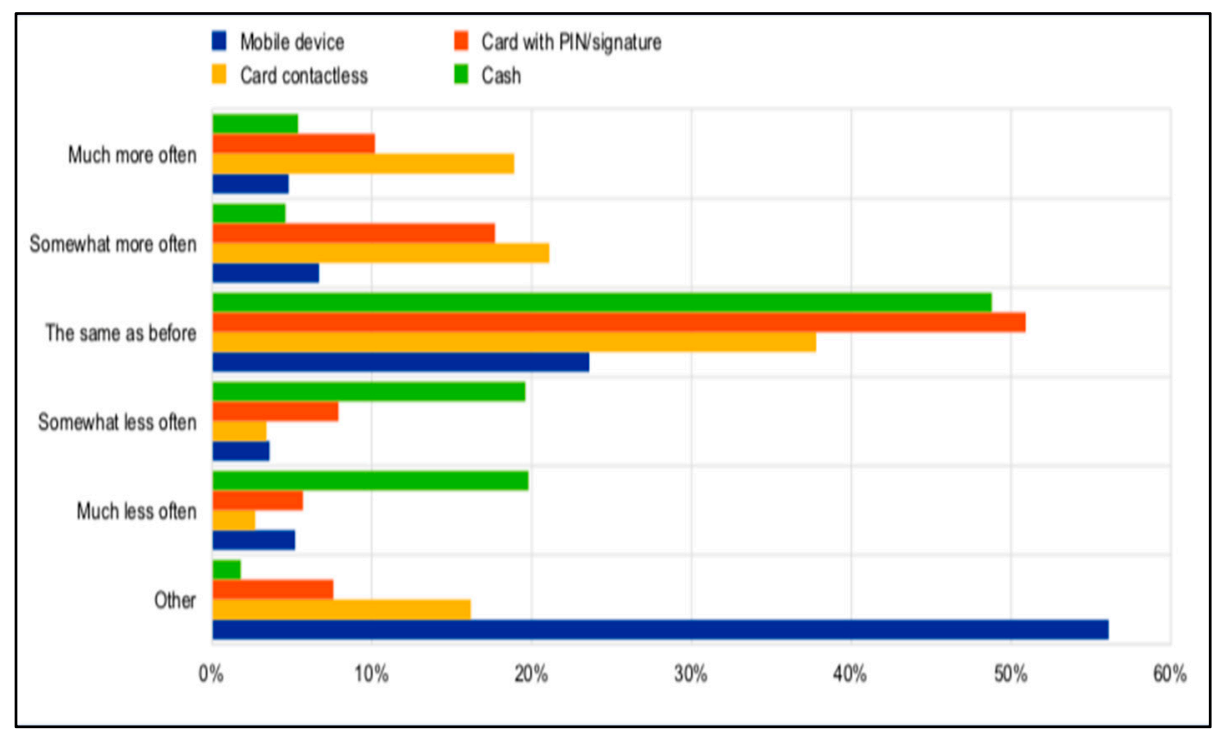

Figure 3. Use of payment methods during the pandemic—source: European Central Bank, 2020.

Given the potential benefits of electronic money and the technological innovation that continues to make this more of a reality by the day, one would imagine that electronic money will soon sound the death knell for physical cash around the globe in the 21st century. We argue that while a significant proportion of countries and peoples, particularly in Europe and North America, are likely to cease using physical cash for electronic money for the vast majority of times, physical cash will still have a place. The place and role of physical cash will be more of a reality particularly in developing economies and for particular transactions and periods even in developed economies, owing to various reasons. Firstly, the potential benefit of electronic money, which comprises traceability, is a drawback in terms of persons who wish to protect their privacy details and avoid surveillance, and even more for those who want to participate in illegal activities (Kahn 2018). Money launderers prefer keeping their identity private and anonymous, and given the power they wield, particularly in narco-states and other countries, they are likely to use the political clout they enjoy to resist a full phasing out of physical cash. Secondly, the nature of technology itself is that it sometimes fails and may experience outages and other breakdown forms. A crash of the technological systems can have a far-reaching and almost catastrophic effect on the commerce world, with payments and transactions failing to go through when the payment system in the form of electronic money fails to work. Thirdly, and related to the second issue, is the potential for cybercrimes by technology gurus, including identity theft, data breaches, and fraudulent transactions. Fourthly, the phasing out of physical cash may have a pernicious effect on the vast majority of people, particularly in developing nations, who barely have bank accounts by further marginalising them and excluding them from the financial system. This would certainly work against the current initiatives towards financial inclusion.

Even over and above the positive attributes of physical cash described above, there are also psychological barriers that may stand in the way of eliminating cash and thus may serve to prevent its full disappearance. Human beings as social beings have a particular tendency to want to associate, feel and connect with things they consider to be of value. Human beings' relationship with money in its physical form of notes and coins goes beyond rationality. For instance, people attach more value to physical notes and coins than electronic money that they cannot easily see or touch, with people considering the money that has since converted to electronic money as less valuable (Uhlmann and Zhu 2013). 
This irrationality that is associated with human beings, quite removed from the economic theory of rationality touted as representing the economic man (homo economicus), is also demonstrated in studies that show that people frown less upon white-collar crime as opposed to a robbery which takes away physical cash or other valuable physical items (Holtfreter et al. 2008). In the end, then, we argue that physical cash will not disappear entirely but will still play a significant role, particularly in some societies more than others. This notwithstanding, a sizeable chunk of physical cash will give way to electronic money in the 21st century.

\subsection{Dominance of Sovereign Currencies}

The emergence of virtual or cryptocurrencies, as discussed above, then puts to the test the continued dominance of sovereign currencies. By sovereign currencies, we mean money issued by states through the central banks. Originally intended to replace sovereign currencies and therefore signal their end, cryptocurrencies may not dominate the world of currencies, at least in this century. This is the likely apparent scenario, at least from the available evidence and assessment of the likely scenarios. A review of some evidence and literature is apt at this point to illustrate this very point. There is still a high demand for cash in most countries (Bech et al. 2018). According to a study, the total market capitalisation for virtual currencies in the United States by November 2018 was around USD 121 billion, while the broad money or sovereign currency was hovering at around USD 17 trillion (Dabrowski and Janikowski 2018).

In contextualising if sovereign currencies will be replaced by private money or virtual currencies, it is critical to examine private money's historical evolution since they are not a new phenomenon. Minimum, virtual currencies are another form of private money that flourished between the 18th century and the start of the 20th century in the UK and the US. Despite the championing of private money by free-market economists in earlier centuries, private money competed poorly against sovereign currencies. This was mainly a function of two factors: network externalities and sovereign currencies' ability to deal with the twin economic problems of information asymmetry and adverse selection. Network externalities in this context refer to the broad acceptability of the sovereign currency by other economic actors and agents capable of performing the various economics functions of money. Historically, this was not possible with other private currencies that mainly operated in opposition to each other.

What is more, the mere existence of many private currencies tended towards higher transaction costs for the various economic actors, thus disincentivising their use. Sovereign currencies were able to deal with this problem, albeit not wholly given the use of foreign currencies, and thus availed a single domestic market for goods and services. Information asymmetry was another economic problem that worked to the disadvantage of private money instead of sovereign currencies. Information asymmetry, which refers to the phenomenon where a financial provider possesses superior information regarding another's creditworthiness or the quality of a particular asset, is a typical feature of all financial intermediation processes. Information asymmetry may lead to excessive risk-taking by financial institutions to the detriment of customers, thereby causing a misallocation of capital and possible financial instability. This argument is one of the justifications for financial regulation.

Within the above context, we need to examine the virtual or cryptocurrencies to decide whether they will replace sovereign currencies as we know them today in the 21st century. First, the virtual currencies in existence, such as Bitcoin, only partially address some economic problems. For instance, the information asymmetry problem is dealt with by the predetermined algorithm employed in their creation and functioning. Their fixed supply also guards against the risk of over-issuance but obviously at the risk of limiting monetary policy targeting. The rise of these virtual currencies is still limited, as most currencies cannot overcome economic problems. One of the reasons for this is that demand for the dollar and the euro is still high since they are considered significant currencies (Jobst and Stix 2017). 
Some governments are also unwilling to accept virtual currencies as legal tenders, yet money depends mainly on the state's stability and acceptance. Finally, the competitive nature of the market for virtual currencies will continue to counter the dominance of any virtual currency, preventing it from overcoming the network's externalities.

The upshot of the immediately preceding paragraph is that sovereign currencies will continue to dominate, particularly in significant currency areas including in Europe and North America, as virtual currencies which appear to pose a threat to their dominance suffer various problems. Unless technological innovation can surmount many of these problems going into the future, it is hard to see virtual currencies replacing sovereign currencies. At best, and in exceptional events such as those featuring hyperinflation, civil wars or financial crisis, virtual currencies may offer a good alternative or a means of currency substitution for respective economies (Dabrowski and Janikowski 2018).

\subsection{Regional Monetary Unions versus Competition between Currencies}

In recent years, there has been a renewed regionalisation of international trade and the creation of preferential trade agreements. In this section, we consider the case of whether we shall also witness the regionalisation of international monetary systems as has been witnessed in Europe with the adoption of a common currency, the euro. Some countries have yielded up their national currencies and instead adopted a common regional currency or a multicurrency monetary union (Jankovics 2004). Eleven member countries in Europe signed the Maastricht Treaty in January 1999, paving the way for forming the European Union. They created a single currency, the euro and a single institution representing the central bank, the European Central Bank (ECB), which is mandated to formulate and implement a single monetary policy for the entire region (Szemeredi 2018).

At the bottom, forming a regional monetary union essentially involves creating a single multinational currency, substituting each nation's currency (Szemeredi 2018). Further, each nation's central bank's monetary policy function is usually transferred to another supranational institution. It is a heavily political and logistical challenge that must have the political will and support of the particular countries' political leadership. The economic rationale for having regional monetary unions is to enhance intra-regional trade, conducive to collective welfare. While the European Union has done relatively well as a regional monetary union, several countries in Central and Eastern Europe, such as Hungary and the Czech Republic, remain out of it (Palankai 2015). In addition, other regional monetary unions such as the Austro-Hungarian union, the Latin and the Scandinavian unions remain defunct, perhaps speaking to the challenges of maintaining such unions, particularly given the political nature of such arrangements (North 2012).

In Africa, monetary unions are contemplated but face various challenges and resistance among some member countries. We argue that this resistance and unwillingness to surrender a country's financial control is an attempt by the respective countries to flex their sovereignty muscle, given that the issuance and control of money is a sovereignty issue (Egedy 2012). We do not see this changing soon because we argue that we are unlikely to see many regional monetary unions in the foreseeable future. There is still insufficient political support for monetary unions in North America with the tension between Canada, the United States and Mexico, and South America with the rise of nationalism in Brazil and Venezuela. Despite the continued growth of intra-regional trade, differences in economic policies and the lack of political support will likely work against regional monetary unions adoption.

In turn, we might see more competition for currencies between national borders that then peters out, leaving two or three significant currencies with a single dominant currency. Alongside increased intra-regional trade will be competition among various national currencies, though the dominant currencies such as the dollar, the euro and the sterling pound will continue to dominate. This is because a multiplicity of currencies works against dealing with network externalities (Toth 2018). As international trade intensifies, countries interact in the trade markets and then in the currency market. Each country issues 
its currency typically, with each country's citizens receiving a domestic currency transfer. The nature of trade entails the exchange of goods and services for a portfolio of currencies. Since sellers accept what buyers hold in the market, the market complementarities lead to various international currencies. In a world with high information costs, an equilibrium featuring two national currencies may arise endogenously, a situation that could hardly be obtained in any other environment. Further, network externalities may lead to coordination failures, thus leading to a single national currency's dominance and the existence of a few substantial or significant currencies.

\subsection{Central Banks and Control over Money}

Much of the discussion and innovations relating to digital cash and virtual currencies have had one of their single most objectives-eliminating central banks or the state from controlling money. In its place is the private sector or actors, including private commercial banks or technology gurus. In this section, we examine who will have control over money and whether central banks will continue to exert their influence over money in the future, especially as they move further towards the digitalisation of money. Granted, and as already canvassed in this paper, the digitalisation of money can shift and alter the financial system's traditional structures by redefining banks' role, including the central bank. However, it is unlikely to erode or even further supplant the central banks' role and control over money. Even if we were to be generous at best and argue that cash will be abolished in the future, a contention we have partially dismissed, it still does not follow that central banks' control over power will be no more, in no small part because this is a political decision.

Take the example of Sweden, one of the countries where electronic or digital money has proliferated, and cryptocurrencies have also been rising in recent years. Even there, the Swedish central bank is loath to cede this control and power over money, as evident in its decision to allow non-banks to have deposits with it. This concept of non-banks holding deposits with the Swedish central bank is known as e-krona (Riskbank 2017). Such a move is in line with the institution of money's traditional stranglehold by the state from long ago when money issuance was a royal prerogative. In this context, we argue that central banks' power to control money is more likely than not secured by the state's political institutions. In our view, this concept of having non-banks hold deposits with the central bank is most attractive as an investment given the safety afforded by central banks. Firms and households with a significant amount of deposits would prefer this mode of saving or deposit keeping as they also escape the risk of a bail-in if commercial banks fail. In times of crisis or economic uncertainty, most customers would choose to have deposit accounts with the central bank and a few of them at commercial banks. Further, there would be a movement of money from commercial banks to central banks.

Further, cryptocurrencies lack any intrinsic value in themselves as money, thereby making them unconvertible. While cash in the form of notes and coins may also not be possessed of any intrinsic value, their recognition as legal tender insulates them from an implosion of the value of money that lacks intrinsic value.

Central Bank Digital Currency (CBDC) can alter the financial sector, especially the banking sector, fundamentally. A Deep Neural Network (DNN) model for the CBDC introduction and how it may affect commercial banks' deposits has been used to estimate the likelihood of bank runs as a function of system characteristics and CBDCs' intrinsic features. The overall success rate of CBDC and the impact on the banking sector depend on its design. CBDC must be interest-free if the amount of CBDC is capped by account or if commercial banks must guarantee convertibility from banks' deposits. Additionally, a CBDC must also help strengthen the financial system's overall sustainability, which is why a CBDC design that supports financial inclusion is essential. Euro area system data are used to calibrate the model at the beginning. It is concluded that an increase in the financial system risk perception would result in a significant transfer of wealth from bank deposits to CBDC; the latter is not affected by its interest rate (Sanchez-Roger and Puyol-Antón 2021). 
Then, the economy is in trouble; monetary policies and adjustments depend on the policy makers' conceptions of money and its functions. There is sufficient consensus among scholars that money is an institution created within the economic system and is in line with other institutions that regulate economic activity. While it is clear that institutions have very different views on what they are and how they work, these views of the working of institutions mean significant differences in monetary enforcement, responsiveness, and stability. Gómez (2019) addresses empirical considerations about money's role in institutional frameworks in discussing institutions' rules and practices. An empirical case study grounds his analysis of Argentina's and the plurality of its currencies in the economy. The study says that while rules guide Argentina's currency, the US dollar was established based on supply and demand principles. As an alternative to traditional and short-term strategy, the big community currency exchanges started during the financial crisis between 1998 and 2002 combined rules and practice. Each of them shows multiple levels of both strength and softness, and fragility.

\subsection{Private Actors and Money Control}

As already hinted, the emergence of cryptocurrencies is geared towards both decentralising and "depoliticising" money. As one of the first calls for money denationalisation, this ambition is not new, which Friedrich Hayek advanced. Riding on the public fame that he had secured after winning the 1974 Nobel Memorial Prize in Economic Sciences and the inflation of the 1970s, Hayek called for the depoliticisation of money and the delinking of money from politics. Hayek envisioned the emergence of private money or currencies by eliminating government monopoly over money and instead vouching for the private issuance of money. To Hayek, no government could certainly be trusted with this monopoly over money as it is wont to abuse it, attributing the inflation of this period to abuse by governments and the "exclusion of ... money from itself being regulated by the market process" (Hayek 1976). While Hayek's vision of private currencies was not obtained in the ensuing decades, his ideas partly carried the day as the fiat currencies devised were operated by semi-depoliticised technocrats in independent central banks. States relinquished most of their political responsibilities but still nominally retained their control over currencies (Eich and Tooze 2015). What ensued was unprecedented growth in the size of private credit money in the form of new financial instruments, a depoliticised economic relation and enforced fiscal discipline.

Fast forward to the 2008-2009 global financial crisis that began in the United States and later spread to Europe, and the relative lull and unquestioning of the erstwhile economic system was put to the test. As central banks and governments scrambled to rescue the financial system from a cataclysmic collapse by bailing out the financial institutions using taxpayers' money, it quickly became clear that the then-prevailing understanding of money as apolitical and neutral was only an illusion. By acting as a backstop to the financial system in socialising losses, the state succeeded in saving the financial system. It was also apparent from this financial crisis that private credit money had in large part replaced the currency, seriously denting any erstwhile presumption that money could be accountable to politics. Central banks found it difficult to exert full control over the financial system due to its complexity, sheer scale and financial innovation, leading to the emergence of complex financial instruments that represented money. It only became clear to them that the last decades had led to a "deterritorialisation of money" due to economic globalisation and the international integration of financial markets that constrain individual states' competencies in handling monetary and financial affairs (Zimmermann 2013). The Eurozone, in particular, had to deal with this harsh reality during the Eurozone crisis as the respective countries realised that they did not have the tools of monetary policy required to deal with the situation as they had surrendered them to the European Central Bank following regional integration. Central banks can create new money at the click of a button through measures such as quantity. The ease of dealing with the economic recession amazed many and eroded the myth of apolitical money. 
The recognition that money is political and central banks were political institutions as learnt in the aftermath of the financial crisis paved the way for a return to the 1970s Hayekian quest for the complete denationalisation of money and private money removed from the state. It is perhaps worth noting at this juncture that while Hayek castigated central bankers as being the ones to blame for enabling governments to retain their monopoly over money, some central bankers of libertarian leanings still mulled and were impressed by Hayek's ideas of denationalised money. For instance, it is reported that former central banker of the United States, Alan Greenspan, saw technological innovation as having the potential to bring about private money and digital cash (Popper 2015). The vision of Hayek appeared a possibility on 1 November 2008, just a few weeks following the collapse of an investment bank, Lehman Brothers, with the publication of a paper on an online messaging board by an anonymous individual under the pseudonym Satoshi Nakamoto proposing an electronic cryptocurrency known as bitcoin (Nakamoto 2008). The bitcoin was seen as a currency beyond human control by going a step further than Hayek in removing money from the state and commercial banks. At the heart of the supposed problem that bitcoin sought to deal with is the element of trust by enabling the conduct of electronic transactions without relying on human trust (Nakamoto 2008). However, a closer interrogation of bitcoins' operation indicates that they are also guilty of the very centralisation and politicisation they denigrate and seek to replace. In particular, the bitcoin mining algorithm tends to favour the large bitcoin miners representing a largely oligopolistic structure, implying that neither the creation nor the confirmation of bitcoin payments is decentralised-they are highly concentrated among large conglomerates who are often anonymous.

With its underlying blockchain technology, the claim that bitcoin seeks to address the age-old problem of trust in human relations, while accurate, also requires a significant amount of trust. This is especially so when one considers that extant cryptocurrencies rely mainly on other communities of crypto adopters' trust. The adoption of bitcoin in the first place was essentially a representation of trust among human beings who were the founders. This leads us to the inevitable conclusion that blockchain and cryptocurrency payments require trust just as much as money is political. Put differently, while bitcoins and other cryptocurrencies seek to project an external image of being decentralised, apolitical and non-reliant on human trust, nothing can be further from the truth. They still rely on central authorities cleverly embedded within the algorithm and usually confused for network and market power. Rather than radically breaking away from politics, cryptos operate well within the politics of money. Indeed, bitcoins and cryptos' attempt to deny politics and central authority is politics in itself and further validates our argument that money is inescapably political.

Table 1 shows the top ten cryptocurrencies by market capitalisation in 2021. Bitcoin was created by Satoshi Nakamoto in 2009 with the aim that it be used to make purchases only through the internet. On 7 January 2021, the price of 1 Bitcoin reached USD 40,000 for the first time. Ethereum is the most actively used blockchain and the second-largest cryptocurrency by market capitalisation, after Bitcoin.

Table 1. Top 10 cryptocurrencies by market capitalisation (20 January 2021).

\begin{tabular}{cccc}
\hline Rank & Name & Price & Market Capitalisation \\
\hline 1 & Bitcoin & USD 35,032.64 & USD 652,251,769,635 \\
2 & Ethereum & USD 1340.45 & USD 152,924,932,110 \\
3 & Tether & USD 1.00 & USD 24,757,509,926 \\
4 & Polkadot & USD 17.76 & USD 16,274,356,276 \\
5 & XRP & USD 0.2914 & USD 13,234,496,586 \\
6 & Cardano & USD 0.3693 & USD 11,579,225,544 \\
7 & Litecoin & USD 147.13 & USD 9,768,509,098 \\
8 & Bitcoin Cash & USD 495.04 & USD 9,188,190,040 \\
9 & Chainlink & USD 21.41 & USD 8,524,020,491 \\
10 & Binance Coin & USD 42.14 & USD 6,518,385,750 \\
\hline
\end{tabular}


The market capitalisation of all the cryptocurrencies from 2016 to 2021 is presented in Figure 4 . The market capitalisation of cryptocurrencies was very high during the year 2018 . The prices later decreased tremendously after that for a year. The market capitalisation remained constant between 2019 and 2020. This year, the prices have skyrocketed during the first quarter.

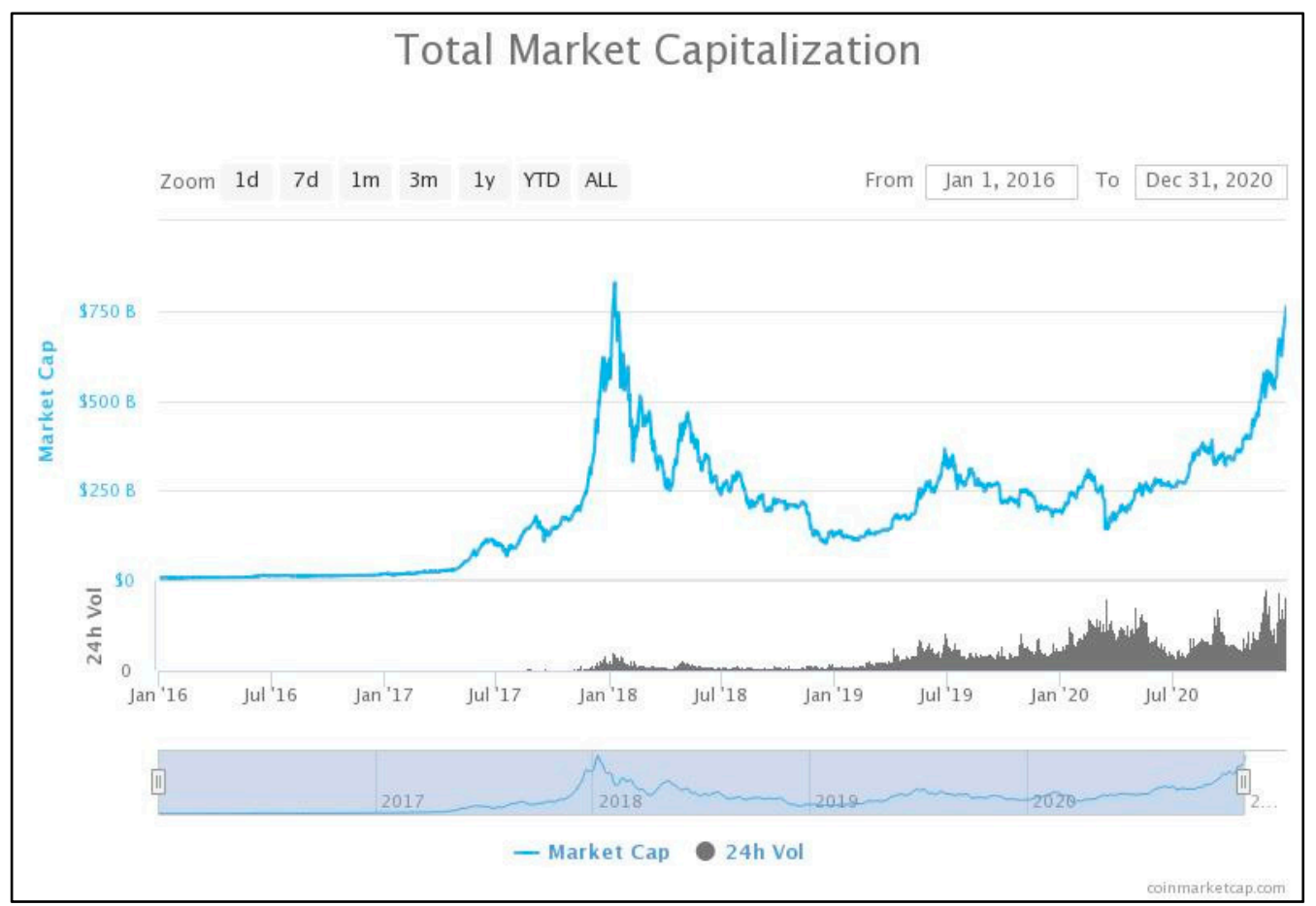

Figure 4. Market Capitalisation. Source: Coinmarketcap, 2021.

Suppose we are to accede to the argument developed in the previous paragraph that money is inherently political and cryptocurrencies, with all of their inventions and assertions to the contrary, are also centralised and political. In that case, it then follows that there is a need to "depoliticise" money. Indeed, the conclusion drawn from these realisations is that rather than seek to depoliticise money, which is a near-impossible feat, we should focus our attention on ensuring that we shape this fictional institution of money according to our political values. Furthermore, this may best be carried out when states or governments still retain some control over the money in whatever form it takes. As such, we argue that despite the increasing influence of private actors, private banks and cryptocurrencies, the state through central banks will continue to exert control over money given the inherently political nature of money. This is evident in the willingness of central banks such as the Bank of England and the Bank of Canada to consider issuing digital currencies and cryptocurrencies of their own to compete with those by private actors (Broadbent 2016).

\subsection{Econometric Analysis}

In this study, we developed a multiple linear regression model for the Euro area with the following variables (values are selected for each month from 31 January 2011 to 31 December 2020). Table 2 provides the description of the dependent and independent variables. Table 3 reveals the descriptive statistics. 
Table 2. Explanatory variables considered in the regression models.

\begin{tabular}{|c|c|c|c|}
\hline Variable & Description & Unit & Source \\
\hline M1 & $\begin{array}{l}\text { Monetary aggregate M1 vis-a-vis euro } \\
\text { area non-MFI excl. central gov. reported } \\
\text { by MFI and central gov. and post office } \\
\text { giro Inst. in the euro area (index) }\end{array}$ & Percentage change & $\begin{array}{l}\text { European Central Bank } \\
\text { (Balance Sheet Items) }\end{array}$ \\
\hline HICP & $\begin{array}{c}\text { The harmonised index of consumer } \\
\text { prices-Overall index }\end{array}$ & Percentage change & $\begin{array}{c}\text { European Central Bank } \\
\text { (Indices of Consumer Prices) }\end{array}$ \\
\hline EURIBOR & $\begin{array}{c}\text { Euro Interbank Offered Rate (Euribor) } \\
\text { 3-month-Historical close, an average of } \\
\text { observations through period }\end{array}$ & Per cent per annum & $\begin{array}{l}\text { European Central Bank } \\
\text { (Financial market data) }\end{array}$ \\
\hline US/EURO & US dollar/euro & US dollar & $\begin{array}{l}\text { European Central Bank } \\
\quad \text { (Exchange Rates) }\end{array}$ \\
\hline BITCOIN & USD value of Bitcoin & US dollar & $\begin{array}{c}\text { Official Data } \\
\text { Foundation/Alioth LLC }\end{array}$ \\
\hline
\end{tabular}

Table 3. Descriptive statistics.

\begin{tabular}{cccccc}
\hline Variable & Obs. & Mean & Std. Dev. & Min. & Max. \\
\hline M1 & 120 & 7.525 & 3.067 & 1.200 & 15.600 \\
\hline HICP & 120 & 1.215 & 0.954 & -0.600 & 3.000 \\
\hline EURIBOR & 120 & 0.068 & 0.557 & -0.538 & 1.598 \\
\hline US/EURO & 120 & 1.212 & 0.110 & 1.054 & 1.444 \\
\hline BITCOIN & 120 & 3039.263 & 4177.530 & 0.300 & $18,795.200$ \\
\hline
\end{tabular}

Table 4 shows the Pearson's correlations coefficient of the variables. There are negative associations between HICP, EURIBOR and EURO. BITCOIN has a positive correlation of 0.491 .

Table 4. Pearson's correlation coefficient of variables.

\begin{tabular}{cccccc}
\hline & M1 & HICP & EURIBOR & USD/EURO & BITCOIN \\
\hline M1 & 1.000 & & & & \\
HICP & -0.761 & 1.000 & & & \\
EURIBOR & -0.812 & 0.606 & 1.000 & & \\
US/EURO & -0.715 & 0.466 & 0.789 & 1.000 & \\
BITCOIN & 0.491 & -0.215 & -0.564 & -0.363 & 1.000 \\
\hline
\end{tabular}

The R-Square of 0.81 shows that M1, HICP, EURIBOR, USD/EURO and BITCOIN contribute $81 \%$ of the regression model variance (Table 5). M1 includes cash in circulation, funds on settlement and current bank accounts. The results of the multiple regression model show that if the HICP increase, the European population will keep their money in longer-term deposits or transfer their accounts to foreign banks, including cryptocurrency. Additionally, if EURIBOR and USD/EURO increase, the money supply will reduce. Ceteris paribus, by increasing the price of bitcoins in the economy, the money supply will increase. 
Table 5. Multiple linear regression model.

\begin{tabular}{cc}
\hline Variable & Dependent variable: M1 \\
\hline Constant & $\begin{array}{c}17.409^{* * *} \\
(2.188)\end{array}$ \\
HICP & $\begin{array}{c}1.485^{* * *} \\
(0.176)\end{array}$ \\
\hline EURIBOR & $-1.342^{* * *}$ \\
& $(0.407)$ \\
\hline US Dollar/EURO & $-6.892^{* * *}$ \\
& $(1.817)$ \\
\hline \multirow{2}{*}{ BITCOIN } & $0.001^{* *}$ \\
& $(0.000)$ \\
\hline $\mathrm{R}^{2}$ & 0.81 \\
\hline ** Significant at the $5 \%$ level. *** Significant at the $10 \%$ level.
\end{tabular}

\subsection{Political or Legal Regime to Ensure Monetary Stability in the Age of Private Money}

We could also explore what could happen if private money, as envisioned by Hayek, came to rule the world in the future. Given that central banks, in their monetary policy exercise, can ensure price stability and ensure the value of money by guarding against inflation, it is critical to examine what institutions and what regimes, legal or political, would fulfil these essential functions. By this, we mean a situation that we may call a "free banking system" without a central bank as the regulator, supervisor and in charge of monetary policy. However, the absence of such institutions regulating cryptocurrencies seems to allow extreme value fluctuations such as the $20 \%$ increase in the value of Bitcoin following a tweet by Elon Musk (Hackett 2021).

Importantly, it needs to be noted that this is not entirely unconventional. It was a feature of late 18th and early 19th century Scotland during economist Adam Smith's time. During this period, Scotland enjoyed a stable financial system which mainly arose from the pressure of private commercial banks that they placed among themselves or on each other to ensure that they behaved in a prudent manner (Selgin 2018). In this scheme of things, it was private banks that had the power to issue money. This self-regulation of banks worked because if a single bank overstretched, its reserves would quickly leak away to other banks, thus placing such a bank at the risk of failure. In essence, the absence of a central bank ensures discipline among private banks by ensuring they exercise restraint in their affairs. Besides, Canada did not have a central bank until the early 20th century, and during that period, it experienced both price stability and financial stability (Selgin 2018). There is some valid argument that central banks lead to instability since central banks' creation can lead to inflation and further blunts private banks' mechanism to discipline each other.

As such, we argue that if there were private money from private banks to replace central banks, there would be no need for a particular legal regime. This is because the private banks would devise a mechanism to self-discipline each other and ensure both financial and price stability in the process.

\subsection{Global Currency}

Regional integration and the resultant regional monetary unions have given rise to debates about the possibility of witnessing a global currency when the whole globe truly becomes a global village, which would entail the collapse of all national boundaries, at least economically, by removing all trade barriers and enabling a free trade flow all over (Andor 2018). Nevertheless, we do not think this is sufficient for us to witness a global currency. Given such a move's political ramifications, we argue that there will be the need for full economic globalisation and political globalisation and a single political authority source for a global currency to arise. Furthermore, given this, we are doubtful to witness a global currency in the 21st century. 
The above conclusion does not take away from the fact that various countries, in particular, regions such as Western Europe, have integrated and adopted a single common currency, the euro. However, Western Europe is only a small part of the globe, and even the Eurozone continues to face problems, including threats of countries pulling away from the union (Johnson 2006). If we look back to the formation of the single currency in Europe, it is not difficult to see that the move had economic and political aspects (Johnson 2006). Therefore, it is critical to look beyond the currency and the economy into the political before making any valid assessment of whether this century will witness a global currency's emergence.

Let us first consider the economic aspects that need to be dealt with for proper integration that can pave the way for a global currency to arise (Andor 2018). There would be a need for increased competition in trade than is currently occurring, which is only possible if trade barriers and other trade constraints are removed at the global level. Such a move is difficult to imagine at the moment considering the nationalist and protectionist movements that have arisen in parts of Central and Eastern Europe, parts of South America, and the United States under President Donald Trump. The ethnic-nationalist sentiments and rhetoric appear to be holding sway and are against the opening up of industries and markets in the economy's particular sectors. This is an antithesis to competition and the possible adoption of a global currency. Secondly, there is a need for the further harmonisation of the financial services sector, which will require collaboration among regulators and the development of legal frameworks globally. This is a political process given that the legislative process in all democracies involves politicians, and it so often happens that political will for such initiatives is frequently missing. Thirdly, there would be a need to change national habits, which would involve giving up some of the tendencies people have become accustomed to. By this, we mean adopting the deferral of tax regimes, opening up borders, and facilitating people and capital's free flow.

\subsection{Use of Money for Legal, Economic Functions}

The evolution of money into its electronic forms and the other transformations that have attended this key institution of money have arguably made it alluring to illicit actors and criminals (Kovacs and Sandor 2016). As stated elsewhere, money serves various legal and economic functions, including being a store of value, a medium of exchange or as a payment system, and a unit of account, among other functions. Therefore, criminals may be incentivised to use money in different criminal activities such as corruption or even financing terrorist networks and activities. Money laundering, a worldwide problem confronting banking scholars, is a pernicious problem principally to the extent that it enables the cleansing of otherwise dirty and illegal money (Schneider 2010). Criminals can launder or clean billions of dollars of money acquired through illicit activities such as drug trafficking through real estate purchases. It, therefore, becomes difficult to trace the source of one's money as an investment whereby such money has been put into perfectly legal investments. Estimates indicate that between 2 to 5 per cent of the total global Gross Domestic Product (GDP), amounting to between USD 800 billion and USD 2 trillion, is laundered annually (UNODC 2016).

Financial institutions deploy significant amounts of resources both financially and in the form of human capital to deal with money laundering. Financial institutions incur substantial regulatory costs to ensure compliance by hiring compliance officers and implementing structures to ensure that money laundering is eliminated or detected. Equally, this comes at a cost to various actors involved in businesses by increasing the transaction costs since due diligence has to be conducted by banks, customers, businesses and others before opening a bank account, depositing money or even withdrawing substantial amounts of cash. To deal with this challenge of money laundering, governments have responded by increasing the regulatory burden on businesses both in quantity and complexity. For instance, the quantity of regulation is estimated to have tripled since the year 2011 to rein in money laundering. 
Technological evolution has also affected efforts to combat money laundering and may thus contribute to the quest to make money perform legal, economic functions only. In this age of big data, the substantial growth in data availability on transactions and individuals involved in almost real-time can help financial institutions and regulators alike to monitor and control money laundering activities. However, financial institutions would need to hire and engage more persons experienced and trained in data analysis and anti-money laundering to tackle this problem. This notwithstanding, there is still insufficient and relevant data, time, and resources to make this ideal a reality. Reliance on old technology, procedures and techniques will hardly do in fighting money laundering.

Whereas traditionally, in the unsophisticated world of laundering, following the money was frequently sufficient in identifying the launderers, it is now essential to also study customers' behaviour. It is quite often the case that a particular customer or business looks legitimate when, in fact, it is not. It needs to be borne in mind that precisely because technology is morally neutral, it targets the bad guys who may wish to conduct illicit and illegal activities. Therefore, while technology has enormous potential to help regulators and financial institutions alike ensure that money is employed for legal, economic functions alone, it may also be used to further malevolent activities. Just like the future of money and combating money laundering appears to be in technology, so does the future of money laundering and other illegal activities. Purchasing and holding assets and holding them for some time before disposing of them while hiding the identity of the real owners of such assets that have formed the substance of money laundering are likely to be replaced by cybercrimes and the use of cryptocurrencies to perpetrate fraud.

Regulators and law enforcement authorities need to consider various measures to ensure that money is only used for legal and economic functions, even in its electronic form. First, regulators could require all financial institutions to record and report all electronic money transactions. Second, regulators need to collaborate with other agencies, seeing that some electronic products in particular countries are usually offered by entities other than financial institutions regulated by the relevant banking law regime. Third, regulators should focus on new and inventive encryption techniques to deal with the technologies and encryption techniques that launderers may employ to make it difficult to access their activities. Fourth, there is a need for continuous dialogue and cooperation between developers and providers of electronic money and electronic money products as this may help detect problem areas concerning law enforcement.

\section{Conclusions}

This paper has considered the lively debate of money's future to establish what money will be in the future. It began by seeking to answer the question of what money is and the economic functions it plays. It then examined the future of physical cash in light of electronic money and digital currency made possible by technological evolution. This paper noted that the various advantages that electronic money has and the inevitable push of technology would lead to an influx of digital money which will largely replace physical cash. However, due to some drawbacks of electronic money and human beings' psychological attachment to physical cash, this paper concluded that physical cash would not entirely disappear. Next, we sought to examine whether a global currency will arise in light of virtual currencies or whether there will be competition for various currencies. This paper argued that it is unlikely that there will be a global currency and that competition between currencies will persist, leading to the emergence of two or three major currencies. It further concluded that cryptocurrencies might not succeed in their quest to replace fiat money issued by central banks. This paper argued that the state would continue to control money through the central banks, given the inescapably political nature of money. This paper also made the case that sovereign currencies backed by the state will continue to dominate and was also melancholic on various regional monetary unions' prospects, given the wave of nationalism worldwide. In the unlikely event that the private sector through private banks replaces central banks in a world of private money, this paper 
argued that there would be no need for an exceptional legal or political regime to ensure price and financial stability as private banks would self-discipline each other to ensure that, as happened in 18th century Scotland. Finally, this paper considered the various ways regulators can ensure that future money, particularly in its digital form, may be used only for legal, economic functions and not illicit activities.

Author Contributions: Conceptualization, D.O. and L.B.; methodology, D.O. and L.B.; software, L.B.; validation, D.O. and L.B.; formal analysis, D.O. and L.B.; investigation, D.O. and L.B.; resources, D.O. and L.B.; data curation, L.B.; writing-original draft preparation, D.O., P.M. and L.B.; writing-review and editing, D.O., P.M., L.B. and Z.Z.; visualization, D.O. and L.B.; supervision, Z.Z. All authors have read and agreed to the published version of the manuscript.

Funding: This research was fully funded by the Hungarian University of Agriculture and Life Science.

Institutional Review Board Statement: Not applicable.

Informed Consent Statement: Not applicable.

Data Availability Statement: Not applicable.

Acknowledgments: Special acknowledgement to the Tempus Public Foundation for the PhD scholarship.

Conflicts of Interest: The authors declare no conflict of interest.

\section{References}

Amiram, Dan, Bjorn Jorgensen, and Daniel Rabetti. 2020. Coins for Bombs-Does Bitcoin Finance Terrorist Attacks? Available online: https:/ / ssrn.com/abstract=3616207 (accessed on 5 February 2021).

Andor, Laszlo. 2018. The Unifying Role of the Single Currency. Inter-Economics 53: 215-20. [CrossRef]

Arvidsson, Nicklas, Jonas Hedman, and Bjorn Segendorf. 2018. When Will Swedish Retailers Stop Accepting Cash? Boras: Swedish Retail and Wholesale Council.

Batrancea, Ioan, Rathnaswamy Malar Kumaran, Batrancea Larissa, Nichita Anca, Gaban Lucian, Fatacean Gheorghe, Tulai Horia, Bircea Ioan, and Rus Mircea-Iosif. 2020a. A Panel Data Analysis on Sustainable Economic Growth in India, Brazil, and Romania. Journal of Risk and Financial Management 13: 170. [CrossRef]

Batrancea, Larissa, Rathnaswamy Malar Maran, Batrancea Ioan, Nichita Anca, Rus Mircea-Iosif, Tulai Horia, Fatacean Gheorghe, Masca Ema Speranta, and Morar Ioan Dan. 2020b. Adjusted Net Savings of CEE and Baltic Nations in the Context of Sustainable Economic Growth: A Panel Data Analysis. Journal of Risk and Financial Management 13: 234.

Bech, Morthen, Umar Faruqui, Frederik Ougaard, and Cristina Picillo. 2018. Payments are changing, but cash still rules. BIS Quarterly Review, March 13.

Broadbent, Ben. 2016. Central Banks and Digital Currencies. London: Bank of England.

Bohte, Rick, and Luca Rossini. 2019. Comparing the Forecasting of Cryptocurrencies by Bayesian Time-Varying Volatility Models. Journal of Risk and Financial Management 12: 150. [CrossRef]

Burn-Callander, Rebecca. 2019. The history of money: From barter to bitcoin. The Telegraph, August 28.

Carstens, Augustin. 2019. The Future of Money and Payments. Basel: Bank for International Settlements.

Dabrowski, Marek, and Lukasz Janikowski. 2018. Can Virtual Currencies Challenge the Dominant Position of Sovereign Currencies? Available online: http:/ / bruegel.org/2018/12/can-virtual-currencies-challenge-the-dominant-position-of-sovereign-currencies / (accessed on 3 May 2019).

Egedy, Tamas. 2012. The effects of global economic crisis in Hungary. Hungarian Geographical Bulletin 61: $155-73$.

Eich, Stefan, and Adam Tooze. 2015. The Great Inflation. In Vorgeschichte der Gegenwart. Edited by Anselm Doering-Manteuffel, Lutz Raphael and Thomas Schlemmer. Gottingen: Vandenhoeck \& Ruprecht.

Gómez, M. Georgina. 2019. Money as an Institution: Rule versus Evolved Practice? Analysis of Multiple Currencies in Argentina. Journal of Risk and Financial Management 12: 80. [CrossRef]

Hackett, Robert. 2021. Bitcoin Surges 20\% after Elon Musk Pumps ‘\#bitcoin’ on Twitter. Available online: https://fortune.com/2021/0 1/29/bitcoin-price-elon-musk-twitter-bio/ (accessed on 5 February 2021).

Hayek, A. Friederich. 1976. The Denationalisation of Money. London: Institute for Economic Affairs.

He, Dong, Ross B. Leckow, Vikram Haksar, Tommaso Mancini Griffoli, Nigel Jenkinson, Mikari Kashima, Tanai Khiaonarong, Celine Rochon, and Hervé Tourpe. 2017. Fintech and Financial Services: Initial Considerations. IMF Staff Discussion Note 17/05. Washington, DC: International Monetary Fund.

Hicks, John. 1979. Critical Essays in Monetary Theory. Oxford: Oxford University Press. 
Holtfreter, Kristy, Shanna Van Slyke, Jason Bratton, and Marc Gertz. 2008. Public perceptions of white-collar crime and punishment. Journal of Criminal Justice 36: 50-60. [CrossRef]

Jankovics, Laszlo. 2004. Roadmap for the adoption of the Euro in Hungary: dangers and opportunities. Competitio 3: 132-42. [CrossRef]

Jobst, Clemens, and Helmut Stix. 2017. Doomed to Disappear? The Surprising Return of Cash across Time and Across Countries. London: Centre for Economic Policy Research.

Johnson, Juliet. 2006. Two-track diffusion and central bank embeddedness: the politics of Euro adoption in Hungary and the Czech Republic. Review of International Political Economy 13: 361-86. [CrossRef]

Jordan, L. Jerry. 2005. Money and Monetary Policy for the 21st Century. Critical Issues Bulletin. Fraser Institute. Available online: https:/ / www.fraserinstitute.org/sites/default/files/MoneyandMonetaryPolicy.pdf (accessed on 5 February 2021).

Kahn, Charles. 2018. Payment Services and Privacy. Fourth Quarter Federal Reserve Bank of St. Louis Review 100: 337-44.

Koki, Constandina, Stefanos Leonardos, and Georgios Piliouras. 2019. Do Cryptocurrency Prices Camouflage Latent Economic Effects? A Bayesian Hidden Markov Approach. Proceedings 28: 5. [CrossRef]

Kovacs, Levente, and David Sandor. 2016. Fraud risk in electronic payment transactions. Journal of Money Laundering Control 19: 148-57. [CrossRef]

Mikhaylov, Alexey. 2020. Cryptocurrency market analysis from the open innovation perspective. Journal of Open Innovation: Technology, Market, and Complexity 6: 197. [CrossRef]

Munda, Constantin. 2018. Mobile money payments hit Sh3.7trn in 12 months. Business Daily, May 1.

Nakamoto, Satoshi. 2008. Bitcoin: A Peer-to-Peer Electronic Cash System. Available online: https://bitcoin.org/bitcoin.pdf (accessed on 5 February 2021).

North, Peter. 2012. Kaláka and Kör: Green money and mutual aid in Hungary. International Journal of Community Currency Research 8: 24.

Palankai, Tibor. 2015. The Introduction of the Euro and Central Europe. Economics and Sociology 8: 51-69. [CrossRef]

Pavlek, Barbara, James Winters, and Olivier Morin. 2019. Ancient coin designs encoded increasing amounts of economic information over centuries. Journal of Anthropological Archaeology 56: 101103. [CrossRef]

Popper, Nathaniel. 2015. Digital Gold. The Untold Story of Bitcoin. New York: Harper Collins.

Riskbank, Sveriges. 2017. The Riksbank's e-Krona Project. Stockholm: Sveriges Riskbank.

Sanchez-Roger, Marc, and Esther Puyol-Antón. 2021. Digital bank runs: A deep neural network approach. Sustainability 13: 1513. [CrossRef]

Schneider, Friederich. 2010. Turnover of organised crime and money laundering: Some preliminary empirical findings. Public Choice 144: 473-86. [CrossRef]

Selgin, George. 2018. Financial Stability without Central Banks. London: Institute for Economic Affairs.

Shaw, Vicky. 2018. Number of card payments overtakes cash for the first time ever in the UK. Independent News, June 18.

Singh, Gurbachan. 2014. Overcoming Zero Lower Bound on Interest Rate without any Inflation or Inflationary Expectations. South Asian Journal of Macroeconomics and Public Finance 3: 1-38. [CrossRef]

Sveriges Riksbank. 2018a. The Payment Behaviour of the Swedish Population. Stockholm: Sveriges Riksbank.

Sveriges Riksbank. 2018b. Payment Patterns in Sweden 2018. Stockholm: Sveriges Riksbank, pp. 1-10. Available online: https: //www.riksbank.se/globalassets/media/statistik/betalningsstatistik/2018/payments-patterns-in-sweden-2018.pdf (accessed on 5 February 2021).

Szemeredi, Eszter. 2018. Innovative initiatives in Hungarian territorial development: The role of complementary currencies. In Some Recent Research from Economics and Business Studies. Komárno: International Research Institute sro, pp. 166-82.

Toth, I. Balasz. 2018. The Function of Local Currencies in Local Economic Development. Public Finance Quarterly 56: 67-78.

Tullock, Gordon. 1957. Paper Money-A Cycle in Cathay. The Economic History Review 9: 393-407. [CrossRef]

Uhlmann, Eric Luis, and Luke Lei Zhu. 2013. Money is essential: ownership intuitions are linked to physical currency. Cognition 127: 220-29. [CrossRef] [PubMed]

UNODC. 2016. Money Laundering and Globalization. New York: UNODC.

Xie, Tian. 2019. Forecast bitcoin volatility with least-squares model averaging. Econometrics 7: 40. [CrossRef]

Young, M. Alice. 2013. The exploitation of global offshore financial centres: banking. Journal of Money Laundering Control 16: 198-208. [CrossRef]

Zimmermann, Claus D. 2013. The Concept of Monetary Sovereignty Revisited. European Journal of International Law 24: 797-818. [CrossRef] 